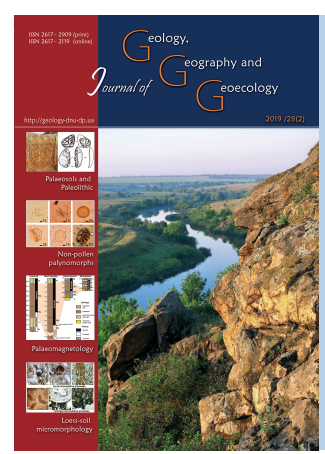

Karmazinenko S.P.

\section{Journal of Geology. Geography and Geoecology}

Journal home page: geology-dnu-dp.ua
ISSN 2617-2909 (print)

ISSN 2617-2119 (online)

Journ.Geol.Geograph. Geology,

28(2), 313-326.

doi: $10.15421 / 111931$

\title{
Pleistocene soils of the Azov Lowland, Ukraine
}

\section{S.P. Karmazinenko}

Institute of Geography of the National Academy of Sciences of Ukraine, Kyiv, Ukraine, e-mail: geo-ins@kiev.ldc.net

Received: 31.01 .2019

Received in revised form: 22.04.2019

Accepted: 24.04 .2019
Journ. Geol. Geograph. Geoecology, 28(2), 313-326. humidity, composition, neoplasms, inclusion, transition between horizons, border) and micromorphological (skeleton, plasma, color, aggregation, porosity, organic and clay parts, mineral skeleton, tumors, microstructure) features. Paleopedological studies of Pleistocene soils have allowed to determine the types of these deposits and to follow the dynamics of changes in soil conditions: - warm-temperate with signs and close to subtropical, when formed reddish cinnamon $\left(\mathrm{kr}_{\mathrm{b} 1}\right)$, reddish brown $\left(\mathrm{kr}_{\mathrm{b} 2}\right)$, cinnamonish-brown $\left(\mathrm{sh}_{\mathrm{b} 1}\right)$, reddish cinnamon $\left(\mathrm{sh}_{\mathrm{b} 2}\right)$, dark-colour (meadow reddish cinnamon) merged ( $\left.\mathrm{mrb} 2+\mathrm{mr}_{\mathrm{b} 1}\right)$, reddish cinnamon, brownish, fused saline soils $\left(\mathrm{mr}_{3}\right)$ Kryzhanivka, Shyrokyno and Martonosha soils, which are distinguished by reddish shades of coloring of the profiles, are the most ferruginous, clay, with a large number of nodules witch concentration of organo-iron-clay material; - moderately-warm transition to subtropical - red-brown saline $\left(\mathrm{lb}_{\mathrm{b} 2}\right)$, dark-colour (brownish-cinnamonic) fused $\left(\mathrm{lb}_{\mathrm{b} 2}+\mathrm{lb}_{\mathrm{b} 1}\right)$ heavy loam Lubny soils, with are less clayed, ferruginous and formed in meadow-steppe and steppe conditions (brownish-gray with cinnamonish shades of coloring profiles, the presence of moleholes, complex microaggregation); - moderately variable - humid close to subtropical - cinnamon and cinnamon saline $\left(\mathrm{Zv}_{\mathrm{b} 1}\right)$, reddish-cinnamon saline $\left(\mathrm{Zv}_{\mathrm{b} 2}\right)$, heavy loam Zavadivka soils, which are a transitional variant to temperate climates, although some of the features of the lower Pleistocene soil formation are retained (ferrugination, presence of segregated clusters organo-clay and clay materials, microortshteins); - moderately-warm equally humid - cinnamon-brown $\left(\mathrm{kd}_{\mathrm{b} 1}\right)$, ordinary chernozems $\left(\mathrm{kd}_{\mathrm{b} 2}\right)$, cinnamonish-gray saline $\left(\mathrm{pl}_{\mathrm{b} 1}\right)$, chernozem saline $\left(\mathrm{pl}_{\mathrm{b} 2}\right)$, brown steppe $\left(\mathrm{pl} \mathrm{c}_{\mathrm{c}}\right.$, heavy and medium loam Kaydaky and Pryluky soils, characterized by the grayish shades of coloring of profiles, the presence of moleholes, carbonates, complex microaggregates, pores and are closest to modern soils; - moderately-warm subarid - cinnamonish-brown ( $\mathrm{vt}_{\mathrm{b} 2}$ ) heavy loam Vytachiv soils formed under the influence of turf (the presence of crust, carbonate, complex microaggregates) and brown-liked (cinnamonish-brown color of the profile, spatial structure of clays) of soil formation processes and have no analogues in modern soil cover; - moderately-continental and more arid (dry) - chernozems saline $\left(\mathrm{df}_{\mathrm{b} 2}\right)$, brown saline $\left(\mathrm{df}_{\mathrm{c}}\right)$, desert-steppe fulvous $\left(\mathrm{df}_{\mathrm{c}}\right)$, medium loam Dofinivka soils, with clear features of xeromorphism (low profile power, its carbonate, lack of signs of organo-mineral materials) replacing.

Key words: paleopedology, Pleistocene, palaeosol morpho-, and micromorphology.

\section{Плейстоценові грунти Приазовської низовини території України}

\section{С.П.Кармазиненко}

Iнститут географії НАН Украӥни, м. Київ, Украӥна, e-mail: geо-ins@kiev.ldc.net

Анотація. 3 метою реконструкцій плейстоценових грунтів на території Приазовської низовини (геологічні розрізи біля сіл Безіменне і Мелекіне Донецька область) нами були проведені палеопедологічні дослідження. При їх дослідженні був застосований палеопедологічний метод, що полягав у детальному аналізі їх морфологічних (забарвлення, структура, гранулометричний склад, вологість, складення, новоутворення, включення, перехід між горизонтами, межа) і мікроморфологічних (скелет, плазма, колір, агрегованість, пористість, органічна і глиниста частини, мінеральний скелет, новоутворення, мікроструктура) особливостей. Проведені палеопедологічні дослідження плейстоценових грунтів дозволили встановити типи цих відкладів та прослідкувати динаміку змін умов їх грунтоутворення: - тепло-помірних з ознаками і близьких до субтропічних, коли формувалися червонувато-коричневі $\left(\mathrm{kr}_{\mathrm{b} 1}\right)$, червонувато-бурі $\left(\mathrm{kr}_{\mathrm{b} 2}\right)$, коричнювато-бурі $\left(\mathrm{sh}_{\mathrm{b} 1}\right)$, червонувато-коричневі $\left(\mathrm{sh}_{\mathrm{b} 2}\right)$, темноколірні (лучно-червонувато-коричневі) злиті $\left(\mathrm{mr}_{\mathrm{b} 2}+\mathrm{mr}_{\mathrm{b} 1}\right)$, червонувато-коричневі буруваті злиті солонцюваті (mr $\left.{ }_{3}\right)$ крижанівські, широкинські і мартоноські грунти, які вирізняються червонуватими відтінками забарвлення профілів, $\epsilon$ найбільш озалізненими, глинистими, із великою кількістю ооїдоподібних стяжінь органо-залізисто-глинистої речовини; 
- помірно-теплих перехідних до субтропічних - червоно-бурі солонцюваті ( $\mathrm{lb}_{\mathrm{b} 2}$ ), темноколірні (бурувато-коричневі) злиті $\left(\mathrm{lb}_{\mathrm{b} 2}+\mathrm{lb}_{\mathrm{b} 1}\right)$ важкосуглинкові лубенські грунти, є менш оглиненими, озалізненими і формувалися у лучно-степових $\mathrm{i}$ степових умовах (бурувато-сірі з коричнюватим відтінком забарвлення профілів, наявність кротовин, складна мікроагрегованість); - помірних змінно-вологих близьких до субтропічних - коричневі і коричневі солонцюваті ( $\left.\mathrm{zv}_{\mathrm{b} 1}\right)$, червонувато-коричневі солонцюваті $\left(\mathrm{zv}_{\mathrm{b} 2}\right)$ важкосуглинкові завадівські грунти, які представляють собою перехідний варіант до грунтів помірного клімату, хоча зберігають деякі риси нижньоплейстоценового грунтоутворення (озалізненість, наявність сегрегаційних скупчень органо-глинистої і глинистої речовини, мікроорштейнів); - помірно-теплих рівномірно вологих - коричнювато-бурі $\left(\mathrm{kd}_{\mathrm{b} 1}\right)$, чорноземи звичайні $\left(\mathrm{kd}_{\mathrm{b} 2}\right)$, коричнювато-сірі солонцюваті $\left(\mathrm{pl}_{\mathrm{b} 1}\right)$, чорноземи солонцюваті $\left(\mathrm{pl}_{\mathrm{b} 2}\right)$, бурі степові (plc) важко- і середньосуглинкові кайдацькі і прилуцькі грунти, які характеризуються сіруватими відтінками забарвлення профілів, наявністю кротовин, карбонатів, складних мікроагрегатів, пор і $є$ найбільш близькими до сучасних грунтів; - помірно-теплих субаридних - коричнювато-бурі $\left(\mathrm{vt}_{\mathrm{b} 2}\right)$ важкосуглинкові витачівські грунти, що формувалися під впливом дернового (наявність кротовин, карбонатність, складна мікроагрегованість) і буроземоподібного (коричнювато-буре забарвлення профілю, лускувата структура глин) грунтоутворювального процесів і не мають аналогів у сучасному грунтовому покриві; - помірноконтинентальних і аридніших (сухих) - чорноземи солонцюваті $\left(\mathrm{df}_{\mathrm{b} 2}\right)$, бурі солонцюваті $\left(\mathrm{df}_{\mathrm{c}}\right)$, бурі пустельно-степові (df) середньосуглинкові дофінівські грунти, з чіткими рисами ксероморфізму (мала потужність профілю, його карбонатність, відсутність ознак перерозподілу органо-мінеральних речовин).

Ключові слова: палеопедологія, плейсточен, трунти, морфо-, мікроморфологія.

Introduction. The Pleistocene soils, which started to develop about 2.6 million years ago, are one of the most important indices for palaeogeographical reconstructions of this period. They are peculiar natural indicators, phenomena and «monuments» of the ancient natural conditions of the time of their formation. No wonder the fossil soils are considered as a kind of archaeological paleogeographic information. Paleopedology, the branch of paleogeography (the science about the ancient geographic sphere and the nature of the Earth's surface), which studies ancient (fossil) soils, deals with the study of fossil Holocene, Pleistocene, Pliocene and more ancient soils and deposits (Veklych e. a., 1979).

Prerequisite for conducting paleopedological studies of Pleistocene soils in the Azov Lowland is the presence on the Azov Sea of the outskirts of the Pleistocene and somewhere more ancient Neogene deposits. Since the Azov lowland is a stratotype region of the Pliocene-Pleistocene deposits in the southern part of Ukraine. Paleopedological investigations on this territory (sites near Mariupol, Shirokine village) were conducted by M.F. Veklych, N.O. Sirenko, Zh.M. Matviishyna (Veklych, 1968, 1982; Veklych, Sirenko, 1972; Veklych e. a., 1973) and later by the author (Karmazinenko, 2013, 2014, 2017).

Matherial and methods of research. In the study of Pleistocene soils in the Azov Lowland, a paleopedological method was used which based on the study of morphology (color, structure, granulometric composition, humidity, composition, neoplasm, inclusion, transition between horizons, boundaries) and micromorphological (skeleton, plasma, color, aggregate, porosity, organic and clay portions, mineral skeleton, neoplasms, microstructure) of the features of ancient deposits (Veklych e. a., 1979; Karmazinenko, 2010; Matviishyna, 1982).

In order to reconstruct the Pleistocene soils in the Azov Lowland, the author carried out field paleopedological research of Pleistocene soils of Kryzhanivka (kr), Shyrokyno (sh), Martonosha (mr), Lubny (lb), Zavadivka (zv), Kaydaky (kd), Pryluky (pl), Vytachiv (vt), Dofinivka (df) stratigraphic horizons (Veklych e. a., 1993; Gozhik e. a., 2012) of the villages of Bezimenne (5 clearings) and Melekine (7 clearings) of the Donetsk region. It should be noted that in order to clarify the genesis of the Pleistocene soils, we first used a micromorphological analysis (200 thin section with undisturbed structure were analyzed under a polarization microscope).

Results and their analysis. On the basis of the results of Paleopedological (morphological and micromorphological) studies of Pleistocene soils of Kryzhanivka (kr), Shyrokyno (sh), Martonosha (mr), Lubny (lb), Zavadivka (zv), Kaydaky (kd), Pryluky (pl), Vytachiv (vt), the Dofinivka (df), stratigraphic horizons (Veklych e. a., 1993; Gozhik e. a., 2012), a change of paleogeographic conditions during the specified stages in the Azov lowlands was observed.

Kryzhanivka horizon (OIS - 53-41 (Veklych e. a., 1993; Gozhik e. a., 2012). Kryzhanivka age formation were studied near village Melekine. They represented by soils of climatic optimum: reddish-brown $\left(\mathrm{kr}_{\mathrm{b} 2}\right)$ and reddish-cinnamon $\left(\mathrm{kr}_{\mathrm{b} 1}\right)$. Characteristic features of their morpho- and microstructure are: reddish shades of coloration, ferrugination (studied soils, among all the studied are most ferruginous), clayed, in the microstructure the presence of segregation of clay and iron-clay material, impregnation of the plasma by microcrystalline calcite.

The upper reddish-brown soil of the climatic optimum $\left(\mathrm{kr}_{\mathrm{b} 2}\right)$ in its microstructure reflects the signs of the processes of some transition to steppe of landscapes (the development of simple and complex microaggregates, intense penetration of plasma by microcrystalline calcite in the lower part of the 
profile). Although, the presence of nodules with concentration of iron-clay material, microortshteins in soils is evidence of an alternating humid regime during their formation (Fig. 1).
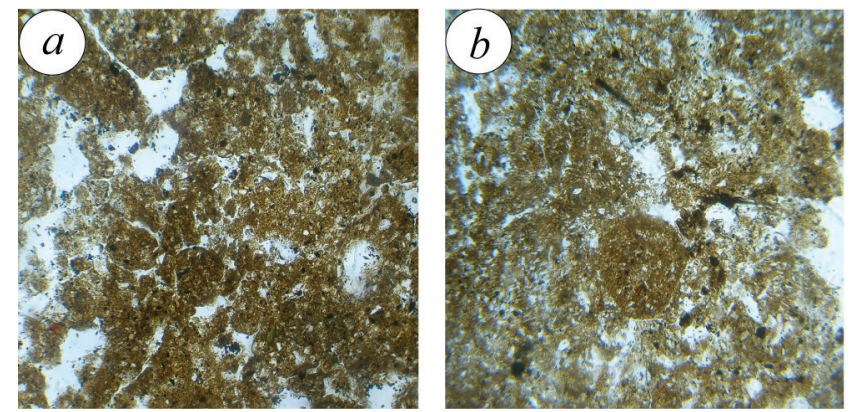

2012). By paleopedological data on the territory of the Azov Lowland were characterized with reddishcinnamon $\left(\mathrm{sh}_{\mathrm{b} 2}\right)$ and cinnamonish-brown $\left(\mathrm{sh}_{\mathrm{b} 1}\right)$ soils, which as Kryzhanivka, are subarid soil formation.
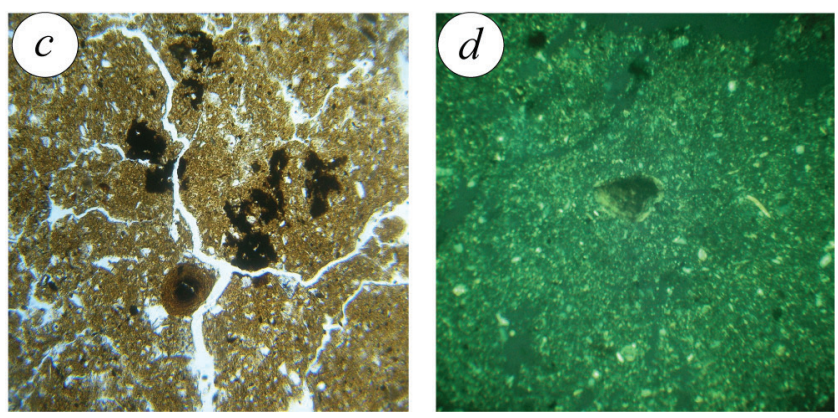

Fig.1. Microstructure of reddish-brown $\left(\mathrm{kr}_{\mathrm{b} 2}\right)$ Kryzhanivka soil (village of Melekine): $a$ - round form of accumulation of iron-clay material; $b$-segregation of iron-clay material; $c$ - iron-manganese stains and microortshteins on the background of iron-clay plasma; $d$ - plasma infiltration by microcrystalline calcite $(a-c-$ nic. $\|, d-$ nic. + , magnification 100$)$

Lower reddish-brown soil $\left(\mathrm{kr}_{\mathrm{b} 1}\right)$ reflects somewhat damper conditions of its formation compared to the upper ones. It is more ferruginous, clayed, in the microstructure, signs of reorientation of clay and iron-clay material with concentrations of ferruginous mull humus in the bundles and lumps are defined. Clay and iron-clay plasma in the lower part is more impregnated with microcrystalline calcite, as well as more intensely colored with oxides and hydroxides of iron and manganese near pores (Fig.2).
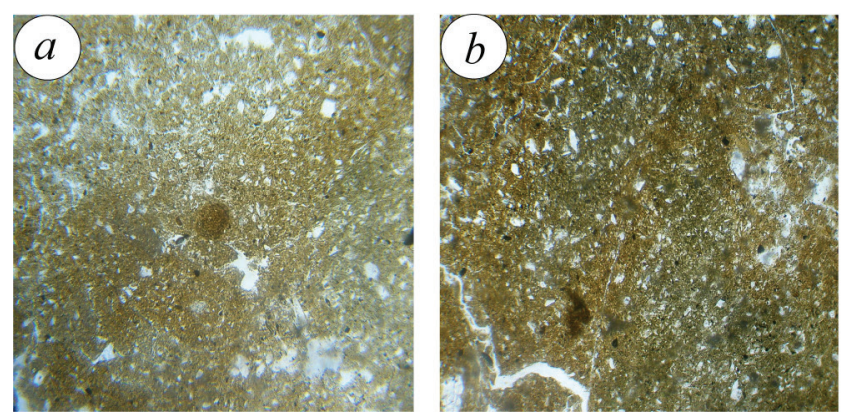

The upper reddish-cinnamon soil $\left(\mathrm{sh}_{\mathrm{b} 2}\right)$, investigated in the section village Melekine, is somewhat lixiviated from carbonates (in the lower part their number increases - carbonate-clay plasma is impregnated with microcrystalline calcite) and is characterized by a nuttish-prismatic structure, an argillaceous composition, in the form of blocks with a large number of nodules witch concentration of organo-clay material (Fig.3). The type of the profile, the intensive ferrugination, claying, which is most
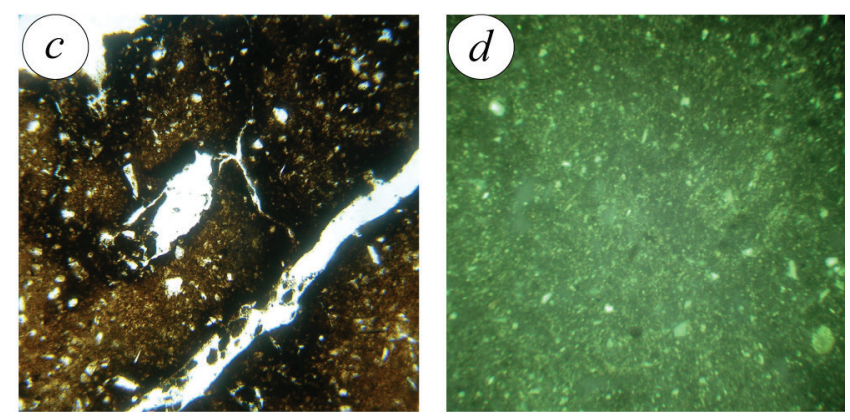

Fig. 2. Microstructure of reddish-brown $\left(\mathrm{kr}_{\mathrm{bl}}\right)$ Kryzhanivka soil (village of Melekine): $a, b$ - signs of displacement of clay and iron-clay material; $c$ - concentration of clay material impregnated with hydroxides and iron oxides and manganese near pores; $d$ - plasma penetration by microcrystalline calcite; $(a-c$ - nic. $\|, d$ - nic. + , magnification 100$)$

The indicated signs (capacity of the profile, clay composition, ferrugination, reddish shades in color) show that formation of Kryzhanivka soil was in a warm, moist (change-humid), close to arid subtropical climate. But at the same time, the soils reflect the intensification of the processes of steppe growing in landscapes (if compare with the northern territories where reddish, red-brown, alkali free forest and meadow soils were formed), they changed with more steppe differences - red-brown $\left(\mathrm{kr}_{\mathrm{b} 2}\right)$ and reddishcinnamon $\left(\mathrm{kr}_{\mathrm{b} 1}\right)$ carbonated.

Shyrokyno horizon (OIS - 35-21) (Gozhik e. a., defined in the middle part of the profile, the features of lixiviation indicate the signs of warmer and humid conditions of soil formation, compared with the Martonosha and Lubny soils of the lower Pleistocene.

The lower cinnamonish-brown soil $\left(\mathrm{sh}_{\mathrm{b} 1}-\right.$ the vil. of Bezimenne) differs from the reddish-brown $\left(\mathrm{sh}_{\mathrm{b} 2}\right)$ stronger profile $(1.50 \mathrm{~m})$, is much clayed, ferruginous, carbonate, with a significant development of complex microaggregates of the I-II order, the presence of nodules with concentration of organo-clay, clay and iron-clay material (their formation is probably connected with meadow processes and with periodic 

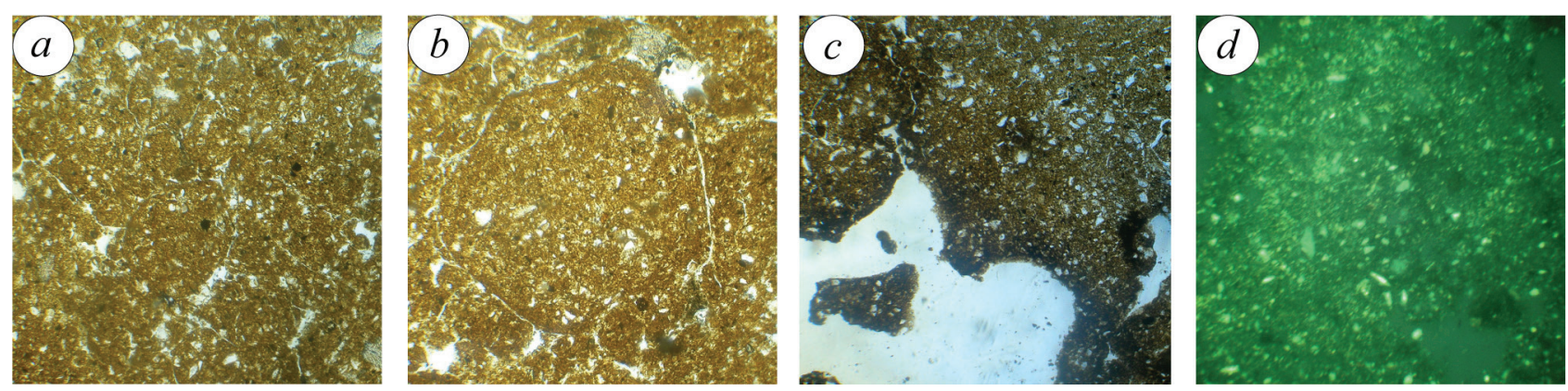

Fig. 3. Microstructure of reddish-cinnamon $\left(\mathrm{sh}_{\mathrm{b} 2}\right)$ Shyrokyno soil (village of Melekine): $a$ - segregational clusters of organo-clay material separated by pores; $b$ - large $(0,7 \mathrm{~mm})$ cluster of iron-clay material; $c$ - carbonate-clay plasma, paintwork pores with oxides and hydroxides of iron and manganese; $d$ - uniform concentration of grains of microcrystalline calcite in plasma; $(a-c-$ nic. $\|, d$ - nic. + , magnification 100)

excess moisture), iron-clay microortshteins (processes of redistribution of iron oxides and manganese, pulling them to the edges of pores-cracks), microcrystalline calcite (Fig.4). All these signs indicate a somewhat wetter conditions for the formation of this soil.

Shyrokyno soils are quite close to the Martonosha
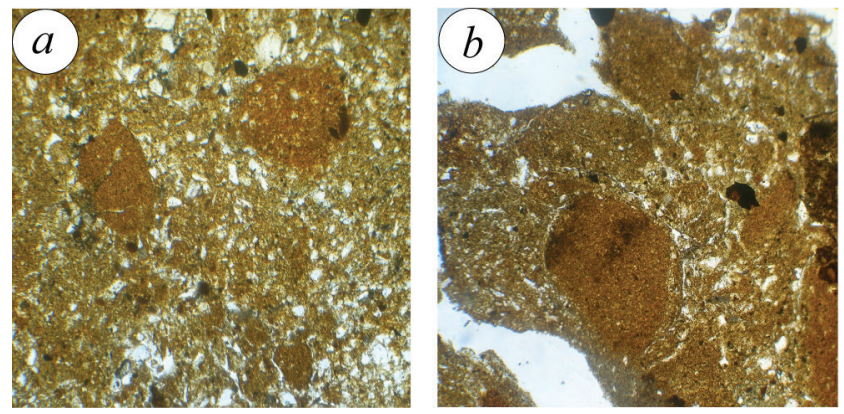

soils (2.0m thickness) were developed. They are characterized by a dark gray with a reddish tinge color of the profile, are more clayed and ferruginous compared with the Lubny and form one polygenetic profile in which some soil formation stages $\left(\mathrm{mr}_{\mathrm{b} 2}+\mathrm{mr}_{\mathrm{b} 1}\right)$ are combined. The meadow-reddish-cinnamon dark-
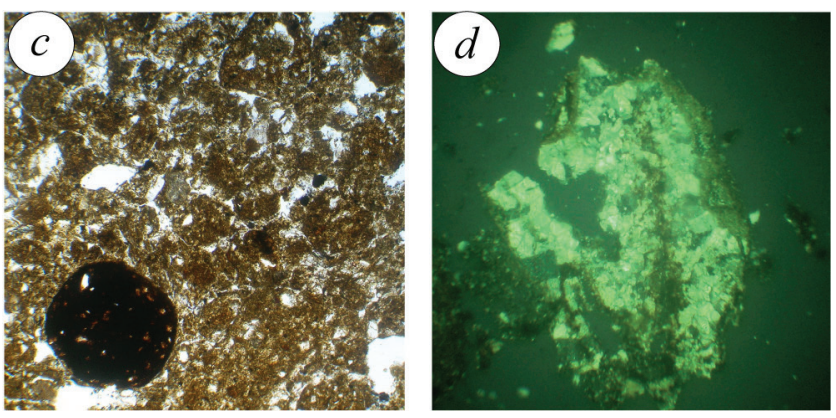

Fig. 4. Microstructure of cinnamonish-brown $\left(\mathrm{sh}_{\mathrm{b} 1}\right)$ Shyrokyno soil (village of Bezimenne): $a$ - uniform impregnarit of plasma by iron-clay material, nodules, clusters of iron-clay material; $b$ - round segregational clusters of clay and ironclay material; $c$ - iron-manganese microortshteins, uniform plasma impregnation with humus and its rounded clusters; $d$-accumulation of fine-crystalline calcite grains $(a-c-$ nic. $\|, d-$ nic. + , magnification 100$)$

signs, but they are characterized by a more intense reddish tinge of the color of the profile, they are more ferruginous (iron-clay plasma), clayed (the number of nodules witch concentration of organo-clay, clay and iron-clay material is much larger). In comparison with the soils which were formed to the north, the studied soils of the Azov Lowland is differed in a higher position of the carbonate horizon, the presence along with the blocks of aggregate microconsolidations and the impregnation of the plasma by microcrystalline calcite in the middle and lower parts of the profiles, indicating somewhat arid conditions of the warmmoderate close to subtropical climate.

Martonosha horizon (OIS - 19-17) (Gozhik e. a., 2012). On the territory of the study during the Martonosha period soils, as in well as the Shyrokyno and Kryzhanivka time, are characterized by a reddish tinge of the color of the profile, are clayed, ferruginous.

Near village of Melekine dark-colored fused colored soil of the climatic optimum $\mathrm{mr}_{\mathrm{b} 2}$ is lixiviated from carbonates ("washed" carbonates accumulate in cinnamonish-brown loess-liked material (Pikgl $\left(\mathrm{mr}_{\mathrm{b} 2}\right)$ ), with carbonate concretions, light carbonateclay plasma and clusters of microcrystalline calcite), with gypsum and shows signs of nettish orientation of clay with spots of manganese in the lower part (Fig.5). The material of the reddish-light-brown dark-colored soil of the climatic optimum, $\mathrm{mr}_{\mathrm{b} 1}$, is more ferruginous (enriched in iron and aluminum compounds), clayed (presence of clay particles) and with carbonate (concretions) compared to the upper $\left(\mathrm{mr}_{3}\right)$. For the soil also characterized by a lesser manifestation of the signs of reorientation of clay and skeletal material and some gleying (meadow formation conditions).

In Martonosha time in the section village of Bezimenne were investigated reddish-cinnamonbrownish fused saline soils $(1.0 \mathrm{~m}) \mathrm{mr}_{3}$ substrage, with features of the steppe (in the upper and middle 

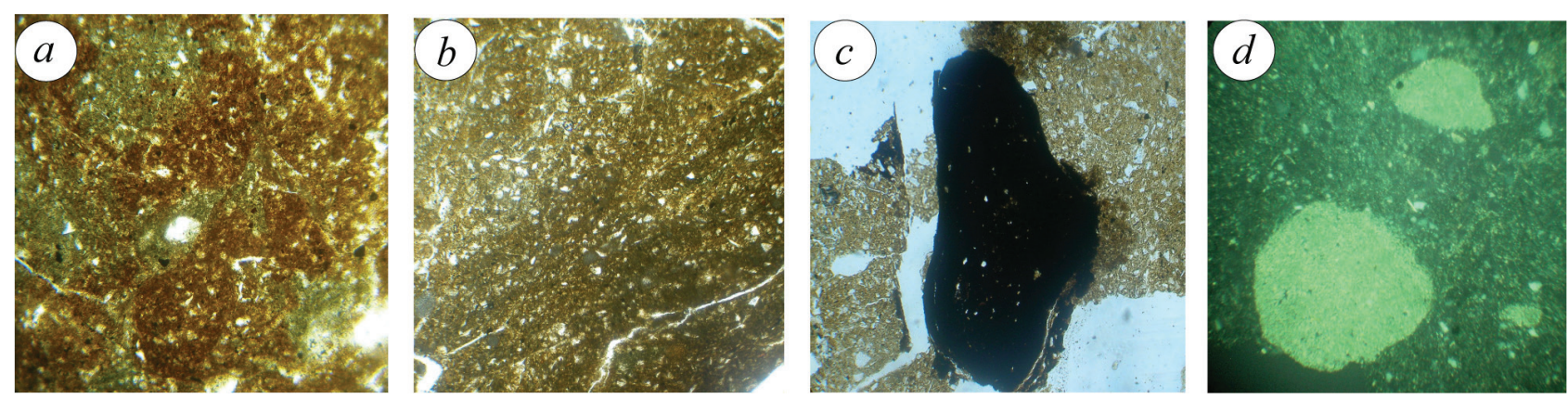

Fig. 5. Microstructure of dark-colored (meadow-reddish-cinnamonic) fused $-\mathrm{mr}_{\mathrm{b} 2}+\mathrm{mr}_{\mathrm{b} 1}$ ) Martonosha soils (village of Melekine): $a$ - rounded clusters of iron-clay material; $b$ - displacement of clay and skeletal material; $c$ - iron-manganese microortshteins elongated form; $d$ - the rounded concentration of microcrystalline calcite in a plasma; $(a-c-$ nic. $\|, d-$ nic. + , magnification 100)

sections of the profile - the development of complex microaggregates to the III order and the nodules witch segregations of the organ-iron-clay material, the isolation of calcite in plasma, and about pores throughout the profile) and meadow (in the bottom the presence of glayed micro-sections and gypsum, slight movement of clay) soil formation (Fig.6).

Compared to the Kryzhanivka and Shyrokyno, the Martonosha soils are characterized by less
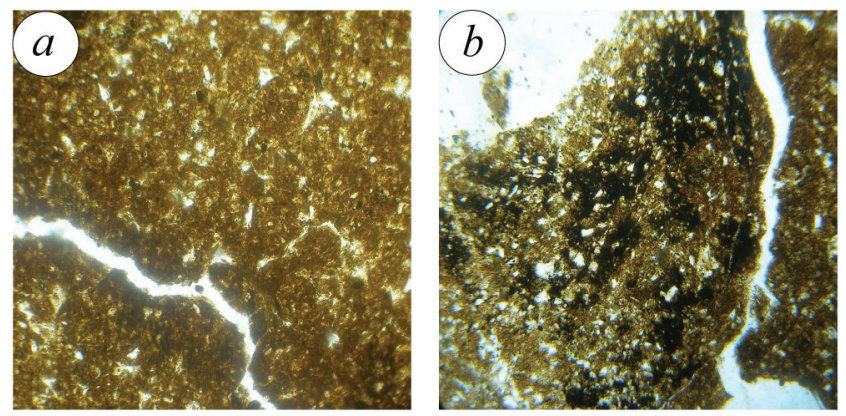

polygenetic profile and reflect an increase in signs of xerophyticity that was characteristic of the conditions of the southern and southeastern parts of Ukraine. All these features indicate the conditions of formation of these enriched, composed in the form of blocks with organo-clay soils, when the climatic conditions were warm-temperate and close to subtropical ones (warmer in comparison with the Zavadivka and especially the Lubny soils). Probably in the first half
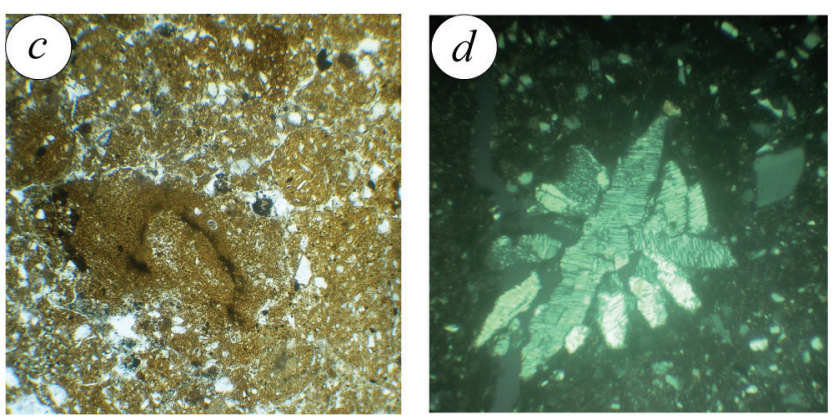

Fig. 6. Microstructure of reddish-cinnamonic fused saline $\left(\mathrm{mr}_{3}\right)$ Martonosha soil (vil. of Besimenne): $a$ - rounded clay segregation separated by pores; $b$-iron-manganese stains; $c$ - signs of the of iron-clay material transfer; $d$-concentration of gypsum in the pores; $(a-c-$ nic. $\|, d-$ nic. + , magnification 100)

thickness of soil profiles, with a lack of well-defined genetic horizons, are not so ferruginous (though they are noticeably enriched in hydroxides of iron and aluminum) and clayed, withless number ofnodules with concentration of organo-iron-clay material. The soils also have dark brown and reddish-dark-cinnamonic color (the highest intensity of reddish coloration in the middle part of the profile), compactness, fusion, high clayed with microforms of some mobility of clays, manganese and iron along the pores with the impregnation of plasma by microcrystalline calcite. All this determines their high viscosity in the humid state and fusibility, density and cracks in drying. Increased Martonosha soil hydromorphism is due, apparently, not only to the abundance of atmospheric precipitation, but also to the close occurrence of ground water. Soils of different stages often form a of the optimum the climate was relatively humid, in the second - the variable-humid, close to the climate of the current alternating-humid subtropics, but with clearly detected hydromorphy of landscapes. This contributed to the development of meadow processes (the formation of powerful profiles with high mineral dispersion), which, in combination with periodic arrigation, rising to the final phase of the Martonian time, caused the fusion of these soils.

Lubny horizon (OIS-15-13) (Gozhik e. a., 2012). Lubny soils, as well as Martonosha, are characterized by the active development of soil formation processes, but in more moderate and more contrasting climatic conditions. This is confirmed by the formation of the soil of the sub-boreal climate on most of the territory of Ukraine at that time, and only in the steppe (including the territory of the Azov lowlands), the Lubny soils 
had some features of the subtropical. The soils of the Lubny horizon are very well expressed in the studied sections, they are characterized by brownish-gray shades of color of their profile, but always with a cinnamonic tint. Only in the Lubny soils in the lower Pleistocene complex microaggregates is developed and humus is concentrated in the humon. They also noted the features that are characteristic to the Kryzhanivka, Shyrokyno and Martonosha soils: some material clayed (more intensively in the middle part of the profile), with compact building, it is characteristic nodules witch concentration of organo-clay material (apparently associated with meadow processes), visible features the movement of clays (mainly within the genetic horizons), iron and manganese in the form of a large number of microortshteins, darker coloration of the pores, simultaneously with the isolation of calcite and gypsum.

The reddish-brown saline soil of the climatic optimum $\mathrm{lb}_{\mathrm{b} 2}$ (vil. of Melekine) has a cinnamonishbrown-reddish coloration of the whole profile (the clayed and density of the middle part), the presence of gypsum concentrations. Micromorphology of the soil is characterized by a manifestation of signs of reorientation of clay material, the presence of clear blocks with concentration of organo-clay material, microortshteins in the middle and lower parts of the profile, which are signs of raining processes and salinization in the formation of soil, due to periodic processes of excess moisture. The presence of complex microaggregates (although their number is negligible), the saturation of carbonates (the impregnation of plasma by microcrystalline calcite and gypsum with its concretions) are signs of the influence of steppe conditions and salinity in the formation of this soil.

In the section of the village of Besimenne an unidentified brown-cinnamonic, dark-colored saline soil, which is characterized by a polygenetic profile $\left(\mathrm{lb}_{\mathrm{b} 2}\right.$ : He, Hpki, Pks and $\mathrm{lb}_{\mathrm{b} 1}$ : Hpk, Pk), was detected. The climate of the climatic optimum $\left(\mathrm{lb}_{\mathrm{b} 2}\right)$ is characterized by the signs of steppe soil formation (lumpy-granular structure, the presence of moleholes and wormholes, the development of complex microaggregates to the third order separated by pores and nodules witch concentration of organoclay material in conjunction with the impregnation of the plasma by microcrystalline calcite). At the same time, its profile is saline in the middle part, with the traces of reorientation of clay and the presence of a significant amount of microortshteins (Fig.7). The lower soil of the climatic optimum $\mathrm{lb}_{\mathrm{b} 1}$ reflects the features of meadow-steppe signs of soil formation and differs in the smaller development of complex microaggregates, but with more iron-manganese microortshteins (periodicity in moisture).

The definite signs indicate that climatic conditions in the territory of the Azov lowland during
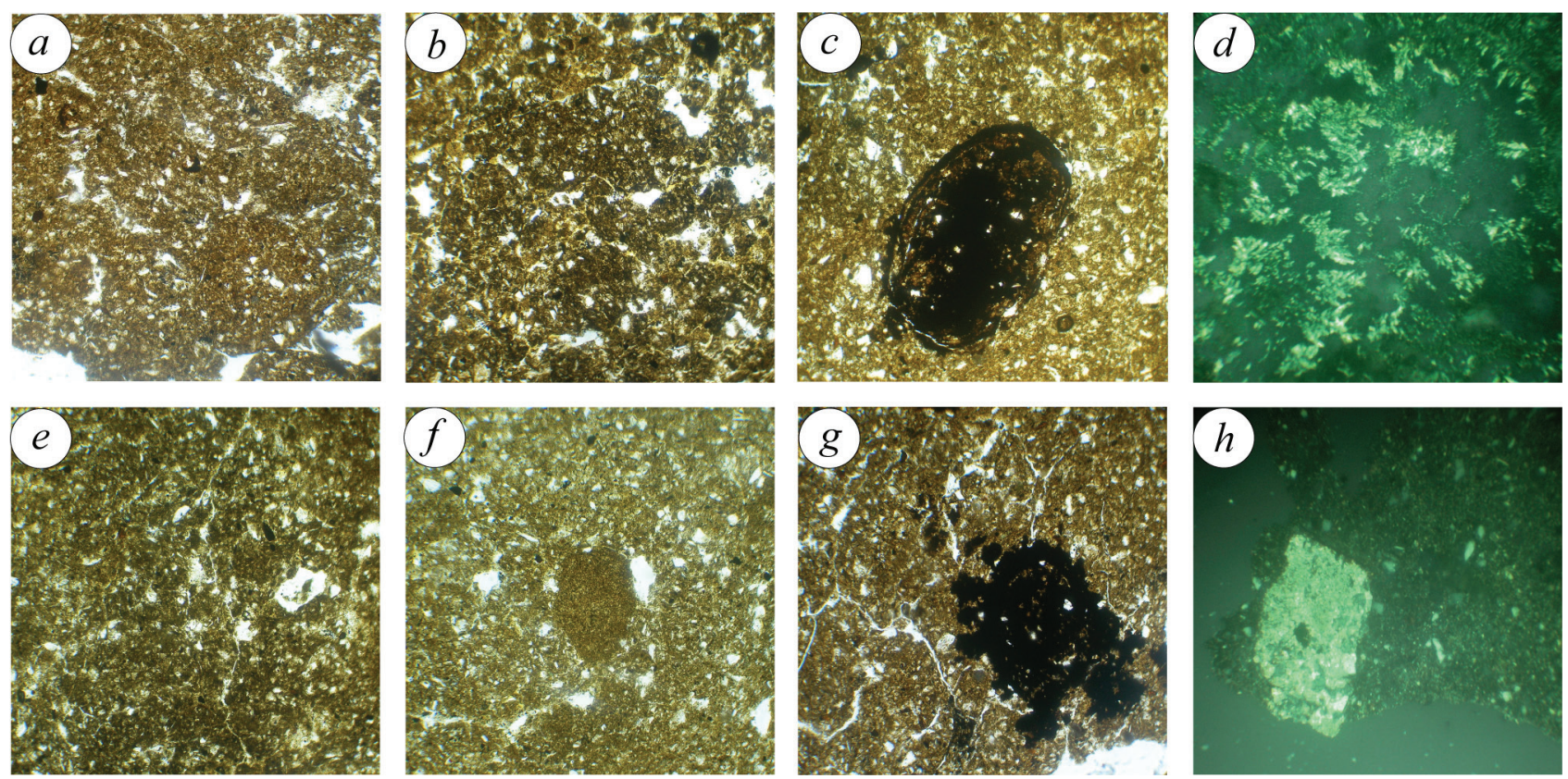

Fig.7. Microstructure of dark-colored (brown-cinnamonic) fused $\left(\mathrm{lb}_{\mathrm{b} 2}+\mathrm{lb}_{\mathrm{b} 1}\right)$ Lubny soil (village of Bezimenne): $a-$ round segregational clusters $(0,2 \mathrm{~mm})$ of iron-clay material; $b$ - complex rounded microaggregates of the I-II order, separated by pores; $c$ - uniform impregnation of the plasma with clay, iron-manganese microortshteins $(0.5 \mathrm{~mm})$ of concentric microstructure; $d$ - small crystals of gypsum; $e$ - complex microaggregates of II order, separated by pores; $f$ - round segregation of clay material; $g$ - there are blocks separated by pores, iron-manganese stain; $h$ - concentration of microand small-crystalline calcite in a pore; $(a-c, e-g-$ nic. $\|, d, h-$ nic. + , magnification 100) 
the formation of the Lubny soils were quite warm, close to subtropical ones (ferrugination, claying and carbonation of the profile), but more moderate and not as warm as in the Zavadivka and Martonosha times. The soils are clayed and ferruginous, but to a lesser extensively than Martonosha and differ from them in grayish shades of coloring profiles. The studied soils are saline, with clear blocks and clutches of organoiron-clay material and features of redistribution of clays within the genetic horizons. The soil $\mathrm{lb}_{\mathrm{b} 1}$ (vil. of Bezimenne) is characterized by a deeper playcing of the carbonate horizon and a large number of microortshteins. The lower soil of the climatic optimum $\left(\mathrm{lb}_{\mathrm{b} 1}\right)$ was definitely formed in meadowsteppe conditions, and the upper $\left(\mathrm{lb}_{\mathrm{b}_{2}}\right)$ - steppe.

Zavadivka horizon (OIS - 11) (Gozhik e. a., 2012). In Zavadivka time were investigated reddish- concentrations of gypsum. Micromorphology of the soil is characterized by the presence of a significant number of segregational clusters of organ-iron-clay material, complex microaggregates of the I-II orders, and the impregnation of the plasma in the carbonate horizon by micro- and small-crystalline calcite (Fig.8).

The cinnamonic saline soils with the chernozemlike profile of the climatic optimum $\mathrm{zv}_{\mathrm{b} 1}$ (vil. of Melekine) differs from the reddish-cinnamonic saline soil $\mathrm{zv}_{\mathrm{b} 2}$ by greater claying, density of profile with cracking pores and drosses of gypsum and manganese puncturing. They are also less ferruginous, aggregated (less complex microaggregates of the I-II order and the separation of organo-clay material on the background of a dense block microstructure with cracking pores) and carbonate and shows signs of a
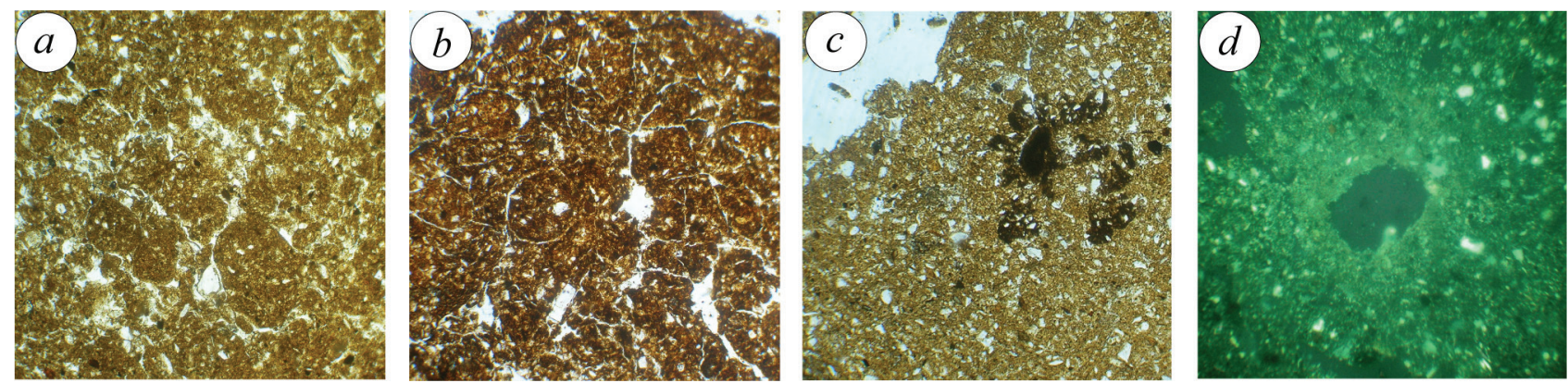

Fig. 8. Microstructure of reddish-cinnamonic saline $\left(\mathrm{zv}_{\mathrm{b} 2}\right)$ Zavadivka soil (village of Melekine): $a$ - nodular segregational clusters of organo-clay material; $b$ - iron-clay plasma, rounded segregational clusters of iron-clay material, separated by pores; $c$-dense packing of skeleton grains in clay plasma, spots of manganese; $d$ - concentration of microcrystalline calcite in the plasma and near the pores; $(a-c-$ nic. $\|, d-$ nic. + , magnification 100$)$

cinnamonic saline $\left(\mathrm{zv}_{\mathrm{b} 2}\right)$, brown saline $\left(\mathrm{zv}_{\mathrm{b} 1}\right)$ the villages of Melekine and cinnamonic soils are also the climatic optimum $\mathrm{zv}_{\mathrm{b} 1}$ (vil. of Bezimenne).

The reddish-cinnamonic saline soil (vil. of Melekine) of the climatic optimum $\mathrm{zv}_{\mathrm{b} 2}$ is characterized by a reddish (ferruginous) shade of the color of the profile, a prismatic-nutty structure, a significant amount of carbonate nodules and slight reorientation of the material (jet orientation of the clay substance, the presence of disaggregated microdistricts and zones depleted on clay - Fig.9). Such signs of the soil indicate its formation in more humid conditions compared with the upper reddishcinnamonic saline soil $\left(\mathrm{zv}_{\mathrm{b} 2}\right)$.

Besides brown saline soils (vil. of Melekine) we also had researched cinnamonic soil of climatic
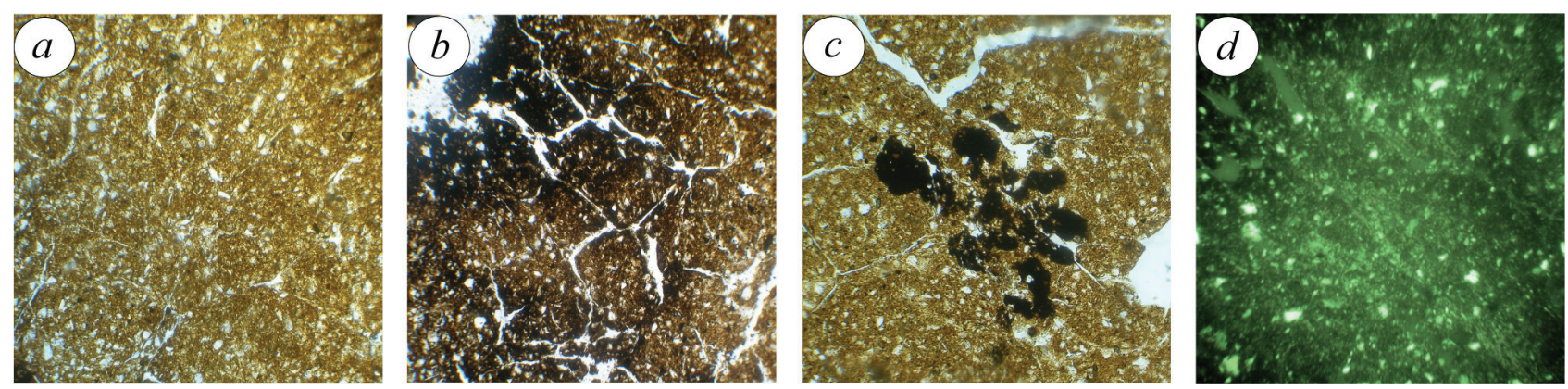

Fig. 9. Microstructure of brown saline $\left(\mathrm{zv}_{\mathrm{b} 1}\right)$ Zavadivka soil (village of Melekine): $a$ - isolation of organo-clay in the form of simple and complex microaggregates of I-II order, separated by twisted pores; $b$ - segregation of organo-clay impregnated with oxides and hydroxides of iron and manganese, separated by pores; $c$ - iron-manganese stains; $d$-dustyplasma microstructure, jet orientation of clay material; $(a-c-$ nic. $\|, d-$ nic. + , magnification 100) 
optimum $\mathrm{ZV}_{\mathrm{b} 1}$ (vil. of. Bezimenne), with a clear horizon of carbonates (carbonates in the form of concretions) and without gypsum. Compared to the soils formed in the north, cinnamonic soils reflect us the features of some soils characteristic for the southern part of Ukraine (the development of complex microaggregates to the III order, the gradual decrease of humus with depth, the presence of the carbonate horizon with carbonate-clay plasma which uniformly impregnated with microcrystalline calcite) and some waterlogging (a significant number of segregation clusters of organo-clay and clay materials, the presence of microortshteins). (vil. of Melekine), is characterized by a browngray coloration of the profile, lumpy structure, the presence of quinces, moleholes and carbonates in the form of veins and nodules. Micromorphologically, the soil is characterized by such microindications (Fig.10): complex microaggregates and porosity (the development of complex microaggregates to the third order, separated by a system of winding pores), various isolation of carbonates (plasma infiltration by microcrystalline calcite, its concentration near pores). Compared to the northern sections, the soil reflects the features of some steppe processes (shortened profile $-0,60 \mathrm{~m}$, the presence of complex aggregates,
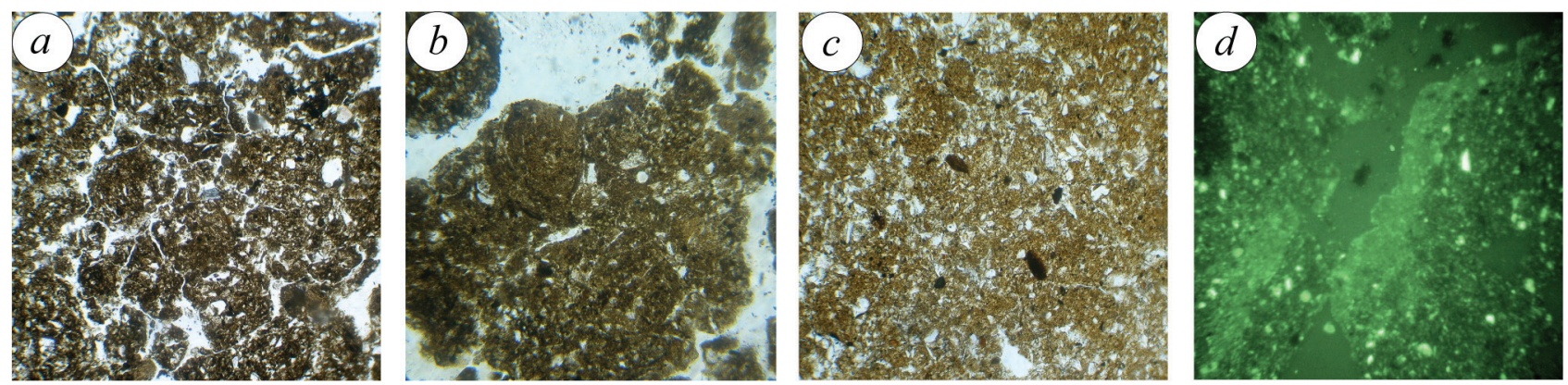

Fig. 10. Microstructure of Kaydaky ordinary chernozem $\left(\mathrm{kd}_{\mathrm{b} 2}\right)$ (village of Melekine): $a$ - humus-clay plasma, complex microaggregates of II-III order, separated by pores; $b$ - plasma impregnation with humus, isolation $(0.2 \mathrm{~mm})$ of organoclay material; $c$ - carbonate-clay plasma, small microortshteins; $d$-concentration of microcrystalline calcite in the plasma and near the pores; $(a-c-$ nic. $\|, d$ - nic. + , magnification 100)

Probably, during the Zavadivka time in the Azov Lowland, the climatic conditions were warmer, even hot, in comparison with modern ones (large ferrugination of soils, often their saline). Although compact structure and inhomogeneous coloration of the profile is characteristic for the Lower Pleistocene (Martonosha, Lubny) soils, in the Zavadivka soils it is also preserved. Probably the soils were formed in moderate variable-humid (in the presence of periods of drying), close to subtropical climatic conditions and represent a transitional version to temperate climates, which became widespread in the post-Dnieper times.

Kaydaky horizon (OIS - 7) (Gozhik e. a., 2012). During the Kaydaky time there were more sharp climatic changes caused by Dnieper glaciation. It's influence also affected the development of soil cover. Instead of the subtropical soils that were distributed in the Pliocene, and in the south and in the Early (Martonosha, Lubny horizon) of the Pleistocene, the temperate continental climate of the Kaydaky period begins to form similar to the modern ones. On the territory of the Azov Lowland, we have investigated the soils of the optimal stage: ordinary chernozem $\left(\mathrm{kd}_{\mathrm{b} 2}\right)$ - village of Melekine and Bezimenne and cinnamon-brown soils $\left(\mathrm{kd}_{\mathrm{b} 1}\right)$ - village of Melekine.

Ordinary chernozem of climatic optimum $\mathrm{kd}_{\mathrm{b} 2}$ impregnation of the plasma by microcrystalline calcite). The climate of the climatic optimum, $\mathrm{kd}_{\mathrm{b} 2}$, according to it's morpho- and microstructure features is most closely related to modern zonal soils (chernozem, the usual) that are developing in this territory, although the climate at that time was definitely a bit more evenly humid.

The lower, cinnamonish-brown soil of the climatic optimum $\mathrm{kd}_{\mathrm{b} 1}$ (village of Melekine) is characterized by a combination of meadow germs (the development of segregation clusters of organo-clay material, signs of weak mobility of silt, plasma penetration by oxides and hydroxides of manganese and its isolation in the form of spots and microortshteins) and steppe (small power, poorly differentiated profile, clear grayish tint in the background of light brown color, complex microaggregating, plasma penetration by microcrystalline calcite in the middle and lower part of the profile) processes of its formation. From the upper $\left(\mathrm{kd}_{\mathrm{b} 2}\right)$ soil, it is differed by less complex microaggregates and carbonates (Fig.11).

According to paleopedological data, it can be concluded that the climatic conditions of the Kaydaky time in the territory of the Azov lowland, as well as for the whole of Ukraine, have changed. In the first half of the optimum the soils of the forest-grass 

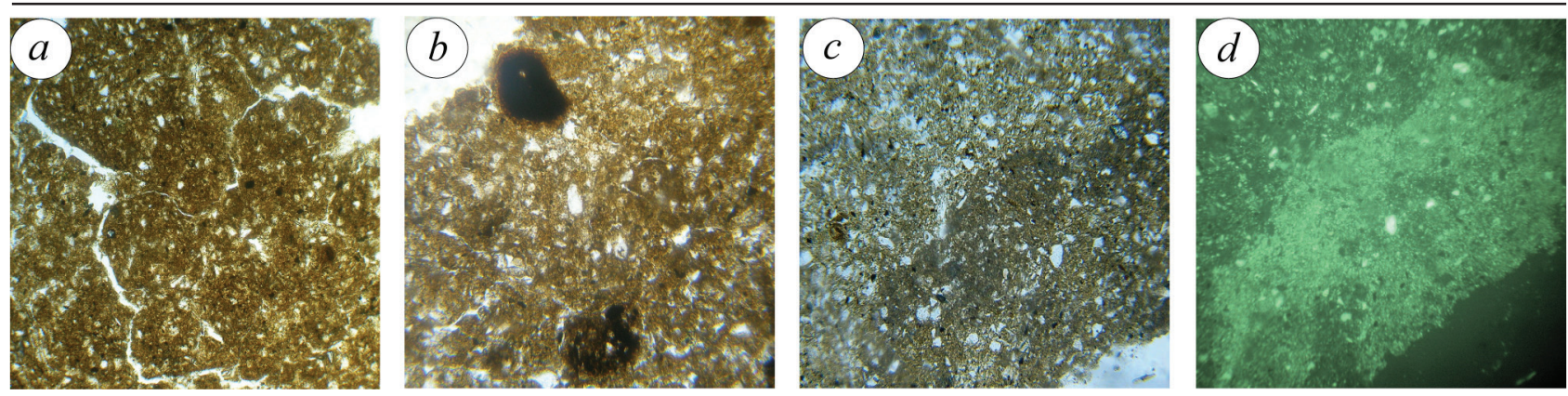

Fig. 11. Microstructure of cinnamonish-brown $\left(\mathrm{kd}_{\mathrm{bl}}\right)$ Kaydaky soil (village of Melekine): $a$ - rounded segregational clusters of organo-clay material separated by pores; $b$ - dense packing of grains of the skeleton in clay plasma, ironmanganese microortshteins; $c$ - plasma impregnation with microcrystalline calcite; $d$ - concentration of microcrystalline calcite in the plasma and near the pores; $(a-c-$ nic. $\|, d$ - nic. + , magnification 100)

genesis were formed. By the end of the stage, the climate has changed considerably in the direction of continentalization - soils of the chernozem type are developing in the soil cover $\left(\mathrm{kd}_{\mathrm{b} 2}\right)$. But the increased meadowness of these chernozems indicates conditions that are more damp than the modern southern zone of chernozem soil formation on the territory of Ukraine. In general, Kaydaky soils reflect more contrasting warmly-moderate conditions of their formation, have a well-formed profile with the genetic horizons of soils of the boreal, sub-boreal type of temperatewarm and temperate continental climate. The features of the upper climatic optimum $\left(\mathrm{kd}_{\mathrm{b} 2}\right)$ resemble the profile of modern soils, but those formed in slightly more evenly humid conditions. Kaydaky soils are most similar to the soils that are currently forming in Ukraine, although some of their features indicate a more humid conditions for their formation, while others are more warm.
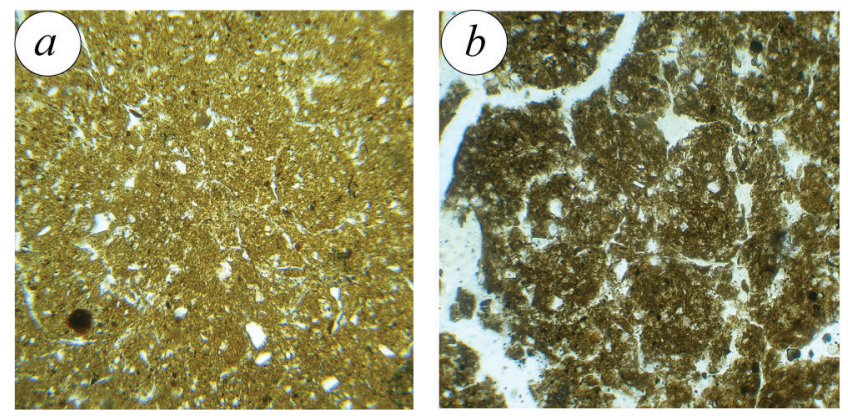

The cinnamonish-gray saline soils of the climatic optimum $\mathrm{pl}_{\mathrm{b} 1}$ (village of Melekine and Bezimenne) are characterized by the following signs of morphoand microstructure (Fig.12): dark gray coloration of the profile with a distinct cinnamonish tinge, lumpy-nutty structure, clayed, fusion, well formed carbonate-gypsum horizon, the development of complex microaggregates to the III order, separated by pores, the dispersed state of humus, the presence of microortshteins, grains of micro- and small crystalline calcite and gypsum of leafy-plaster form. In the upper part, due to the saline, the soil shows signs of a slight nettish orientation of the clay material. The presence and concentration of a large number of microortshteins indicates a certain periodicity in the moisture of these soils. Apparently, the soils were formed in the conditions of a southern meadow grass steppe of moderately warm climate and combine some of the properties of chernozem and chestnut soils.
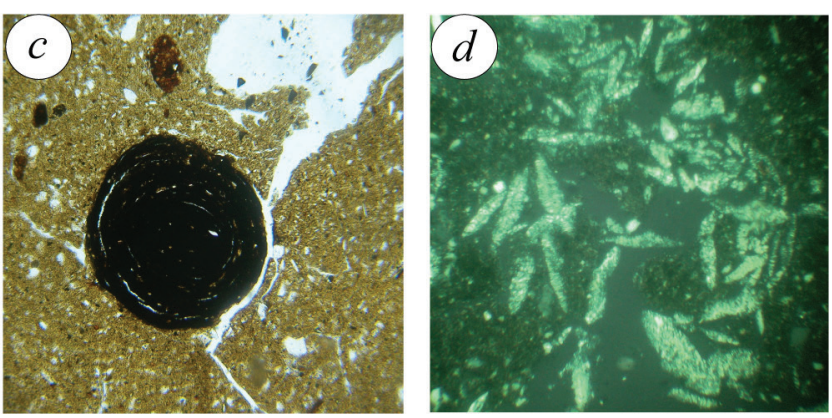

Fig. 12. Microstructure of cinnamonish-gray saline $\left(\mathrm{pl}_{\mathrm{b} 1}\right)$ Plyluky soil (village of Melekine): $a$ - clay plasma of the base, simple and complex microaggregates of the II-III order of a rounded form, separated by thin winding pores; $b-$ round segregation of organo-clay material separated by pores; $c$ - concentric glandular manganese microortshtein; $d-$ concentration of small plaster crystals in plasma; $(a-c-$ nic. $\|, d$ - nic. + , magnification 100$)$

Pryluky horizon (OIS - 5) (Gozhik e. a., 2012). On the territory of the Azov lowland, we were found hear vil. of Bezimenne the svit of Pryluky soils (cinnamonish-gray saline $-\mathrm{pl}_{\mathrm{b} 1}$, chernozem saline $-\mathrm{pl}_{\mathrm{b} 2}$, brown steppe $-\mathrm{pl}_{\mathrm{c}}$ ) and cinnamonish-gray saline soils of the climatic optimum $\mathrm{pl}_{\mathrm{b} 2}$ (village of Milekine).
The chernozem saline of climatic optimum $\mathrm{pl}_{\mathrm{b} 2}$ (village of Bezimenne) is dark gray with a brown tinge with profile color, lumpy structure, the presence of moleholes and carbonates in the form of impregnation and mycelium. The soil, in contrast to the corrosiongray saline soils $\left(\mathrm{pl}_{\mathrm{b} 1}\right)$, is better microagregated over the entire profile (complex microaggregates of the 

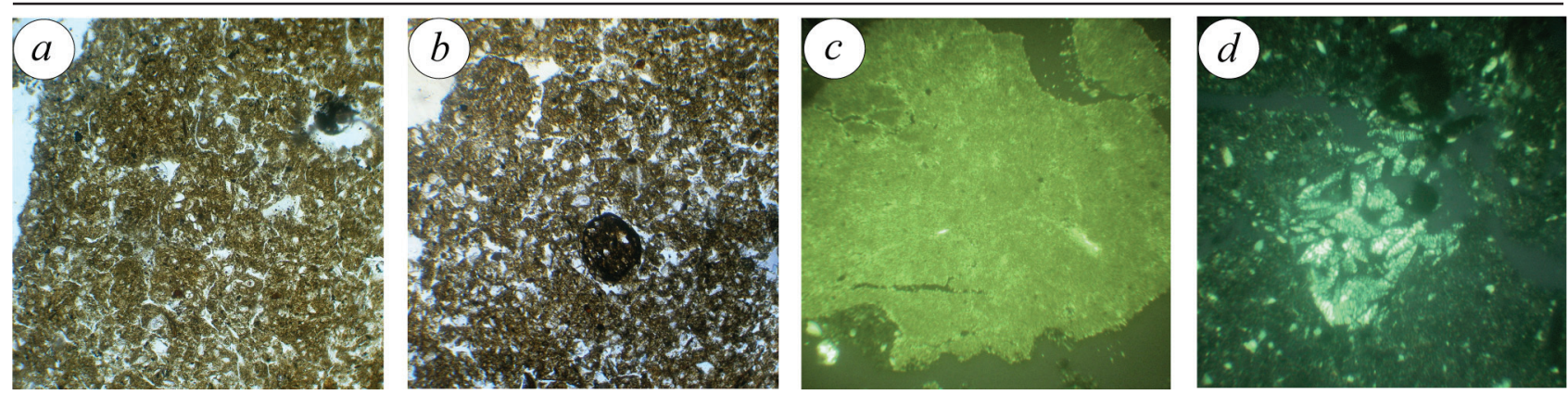

Fig. 13. Microstructure of Pryluky $\left(\mathrm{pl}_{\mathrm{b} 2}\right)$ chernozem saline (village of Bezimenne): $a$ - uniform impregnation of the plasma organo-clay material, simple and complex microaggregates of I-II order, separated by pores; $b-c o m p l e x$ microaggregates of the III order, round form $(0,15 \mathrm{~mm})$, separated by pores, iron-manganese microortshtein $(0,15 \mathrm{~mm}) ; c$ - cluster of microcrystalline calcite; $d$-concentration of gypsum in the pores; $(a-c-$ nic. $\|, d$ - nic. + , magnification 100$)$

I-III order) with the presence of micro- and small crystalline calcite grains in carbonate-clay plasma, but less porous (a small number of gypsum crystals in the upper and lower parts of the profile - Fig.13).

The brown weaclydeveloped steppe soil of the final stage $\mathrm{pl}_{\mathrm{c}}$ (village of Bezimenne) is characterized by poor development of complex microaggregates of the I-II order, uniform saturation of the plasma by microcrystalline calcite.

Pryluky soils - cinnamonish-gray saline $\left(\mathrm{pl}_{\mathrm{b} 1}\right)$, chernozem saline $\left(\mathrm{pl}_{\mathrm{b} 2}\right)$, brown steppe $\left(\mathrm{pl}_{\mathrm{c}}\right)$ reflect conditions of a moderately warm climate (wetter and warmer in comparison with modern ones) of the southern grassland steppe. Soils, forming the suit of soils $\left(\mathrm{pl}_{\mathrm{b} 1}+\mathrm{pl}_{\mathrm{b} 2}+\mathrm{pl}_{\mathrm{c}}\right)$ reflect changes in conditions of moderately warm climate during the stage. The most humid conditions were during the formation of cinnamonish-gray saline $\left(\mathrm{pl}_{\mathrm{b} 1}\right)$, somewhat less humid - chernozem saline $\left(\mathrm{pl}_{\mathrm{b} 2}\right.$ ) and much less moist - brown steppe $\left(\mathrm{pl}_{\mathrm{c}}\right)$ soil. Pryluky soils, as well as Kaydaky are the closest to the soils that are currently forming
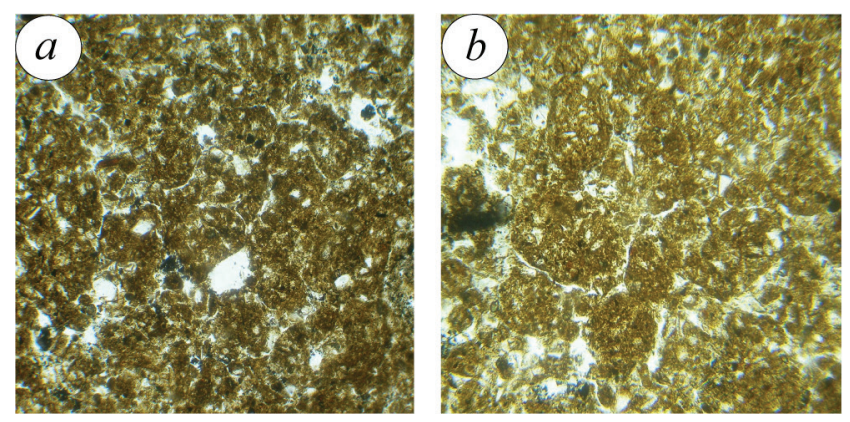

zone, but in more arid conditions (compared to the northern territories). Natural zones of Ukraine at the modern time, in comparison with the Kaydaky, were displaced to the south.

Vytachiv horizon (OIS - 3) (Gozhik e. a., 2012). In the Vytachiv time, the cinnamonish-brown (similar to chestnut) clay optimum $\mathrm{vt}_{\mathrm{b} 2}$ soils (sections the villages Melekine and Bezimenne) were investigated.

Morphologically, the soils are characterized by a cinnamonish-brown coloration of the profile, a considerable clayed of its middle part, with carbonates in the form of impregnation, white bilozirka other and concretion. Under a microscope for soil material, the development of simple and complex microaggregates of the III order is characteristic, as wele us the concentration of the organo-clay material, the spatial structure of the clay, the presence of microortshteins, and the saturation of the plasma by microcrystalline calcite (Fig.14).

Such morpho- (cinnamonish-brown coloring, profile reduction and its riching in carbonates, high
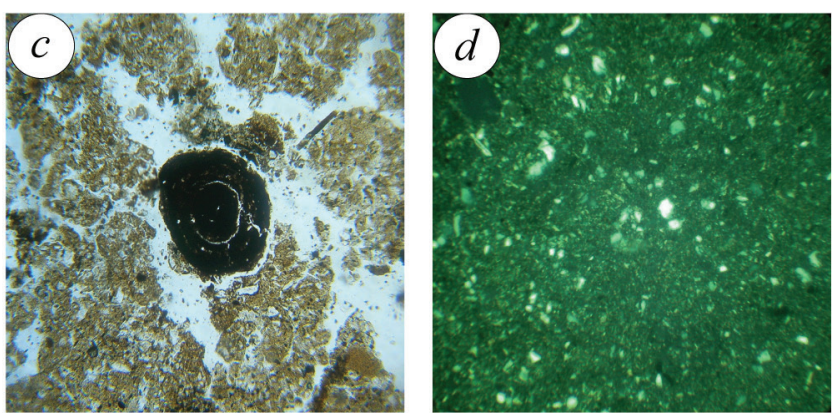

Fig. 14. Microstructure of cinnamonish-brown ( $\left.\mathrm{vt}_{\mathrm{b} 2}\right)$ Vytachiv soil (village of Melekine): $a$ - simple and complex microaggregates of the I-III orders of round form $(0,12 \mathrm{~mm})$, separated by pores; $b$ - nodules with segregations of organoclay material; $c$ - iron-manganese microortshtein $(0.25 \mathrm{~mm}) ; d$-dusty-plasma microstructure, uniform concentration of microcrystalline calcite in plasma; $(a-c-$ nic. $\|, d$ - nic. + , magnification 100$)$

in Ukraine, although some features indicate a more humid conditions for their formation, while others are more warm. In comparison with the Kaydaky, Pryluky soil formation took place in somewhat more steppe conditions, although in one moderately warm absorption, especially in the middle part) and micro sign (the presence of nodules) of soils indicate their development in fairly warm and relatively humid conditions. It is possible that the moisture of these soils was periodic: in the humid season, the 
soil-forming process proceeded in the direction of brownzems formation, and in dry period under the steppe type. Such periodicity of humidification is confirmed by micromorphological data (development of concentration of organo-clay material, concentric microortshteins, along with plasma by microcrystalline calcite). However, the insignificant power of the Vytachiv soils $(0.70 \mathrm{~m})$, the presence of moleholes, high degree of carbonatisation with the isolation of the carbonate horizon indicates rather dry conditions of formation. Probably the Vytachiv soils in this territory have developed in rather warm conditions of periodically arid temperate and warm subarid climate and have no analogues in the modern soil cover.
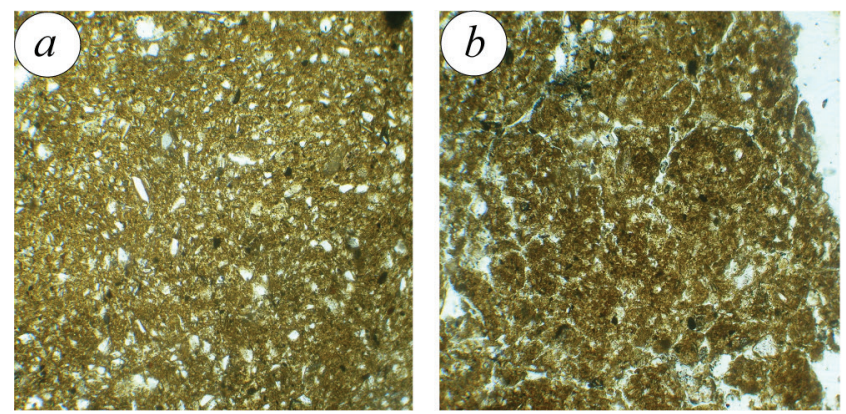

microcrystalline calcite impregnation of plasma, and the presence of tabular gypsum (Fig.15). Compared to the Pryluky saline soils, the chernozem of the Dofinivka time are even with more quatity of gypsum content and have the influx of humus in the middle part of the profile, can see some redistribution of iron oxides and manganese, which are distinguished in the form of thin films along the edges of the pores in the background as well as a whole of the carbonate-clay plasma. Ale this is a confirmation of its formation in conditions of insufficient moisture with clear features of xeromorphism.

In the final ( $\left.\mathrm{df}_{\mathrm{c}}\right)$ stage of the Dofinivka soil formation there were formed: low-power
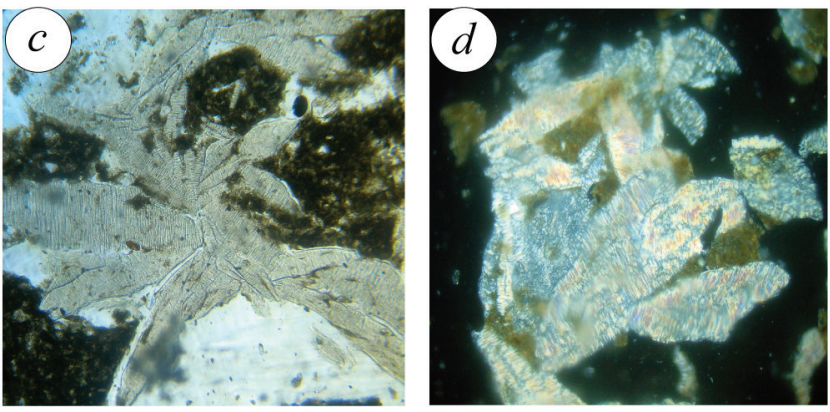

Fig. 15. Microstructure of the Dofinivka $\left(\mathrm{df}_{\mathrm{b} 2}\right)$ chernozem saline (village of Melekine): $a$ - compact packing of grains of the mineral skeleton in the humus-clay plasma; $b$ - simple and complex microaggregates of the III order $(0,1 \mathrm{~mm})$, separated by pores; $c$ - large crystals of gypsum; $d$ - tabular crystals of gypsum; $(a, b-$ nic. $\|, c, d$ - nic. + , magnification 100)

Dofinivka horizon (OIS - 2) (Gozhik e. a., 2012). The morpho- and micromorphological properties of the Dofinivka soils reflect the features of the Pleistocene trends to climate aridisation. This is confirmed by the formation of the chernozem of saline soils $\left(\mathrm{df}_{\mathrm{b} 2}\right)$, steppe brown saline soils and brown desert-steppe soils in the final stage ( $\left.\mathrm{df}_{\mathrm{c}}\right)$ of the Dofinivka soil formation.

The Dofinivka climatic optimum soil $\mathrm{df}_{\mathrm{b} 2}$ chernozem saline (village of Melekine) is characterized by a dark gray color, the presence of moleholes, wormholes, carbonates and niddles of gypsum, the development of simple and complex of I-II order microaggregates,
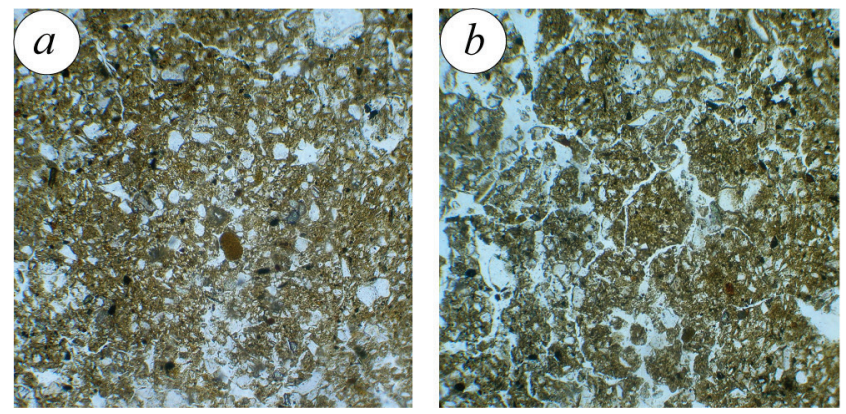

$(0.30 \mathrm{~m})$ fulvous saline soils (simple and complex microaggregates of the II order, uniform impregnation of the plasma by microcrystalline calcite and gypsum) were investigated in the section the villages of Melekine and brown desert-steppe soils (light-boring color, powdery forms of carbonates, spongy microstructure, simple and complex to the II order microaggregates, separated by pores, plasma infiltration by microcrystalline calcite - Fig.16) - vil. of Melekine, Bezimenne.

The morpho-and micromorphological properties of the Dofinivka soils reflect the features of the Pleistocene's subsequent climate aridization.
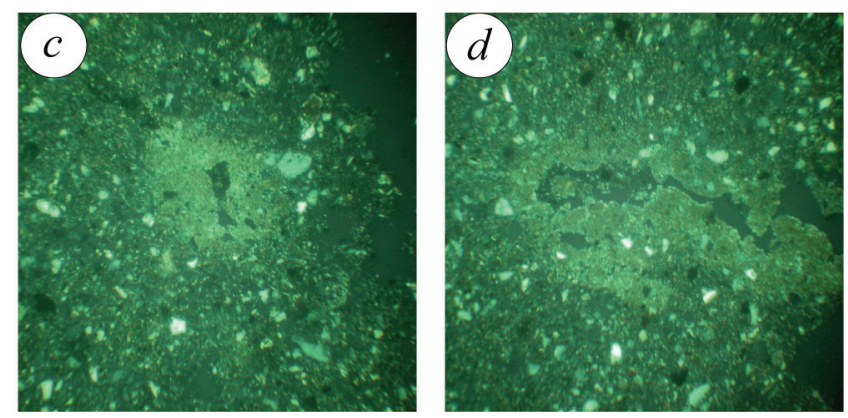

Fig.16. Microstructure of brown desert-steppe $\left(\mathrm{df}_{\mathrm{c}}\right)$ Dofinivka soil (villag. of Melekine): $a$ - compact building, dense packing of grains of mineral skeleton in carbonate-clay plasma; $b$ - complex microaggregates of the II order, separated by winding pores; $c$-dusty-plasma microstructure, concentration of microcrystalline calcite in the pores; $d$-concentration of microcrystalline calcite in a pore; $(a, b-$ nic. $\|, c, d$ - nic. + , magnification 100$)$ 
Insufficient moisture has led to the formation of chernozem, which had clear features of xeromorphism (without signs of redistribution of organo-mineral substances by profile), their profiles are carbonate, often with gypsun. Xerophytization of conditions has been especially intensified in the final stage of the Dofinivka soil formation (the formation of brown desert-steppe soils). The Dofinivka soils, in comparison with modern ones, have a higher aridity of the conditions for the formation of a temperate dry continental climate, but warmer compared with the Prychernomorsk time.

Paleopedological results obtained by the author in person (Karmazinenko, 2013, 2014, 2017) and the usage of literary data (Veklych, 1982, 1987; Krokhmal, Rekovets 2010; Sirenko, Turlo 1986) made it possible not only to reconstruct the Pleistocene soils, but also to follow the change of paleogeographic conditions (types of soils, general types of vegetation, faunistic complexes, and climate) during the Dofinivka, Vytachiv, Pryluky, Kaydaky, Zavadivka, Lubny, Martonosha, Shyrokyno and Kryzhanivka stages in the Azov Lowland (Table 1).

Conclusions. Paleopedological studies (using micromorphological analysis) of the Pleistocene soils of the Kryzhanivka, Shyrokyno, Martonosha, Lubny, Zavadivka, Kaydaky, Pryluky, Vytachiv and Dofinivka stratigraphic horizons near the villages of Bezimenne and Melekine in the Azov Lowland made it possible to determine their morpho- and micromorphological features, to establish the types of these deposits and to reconstruct the paleogeographical conditions of the time of their formation:

- Kryzhanivka (reddish-cinnamon - $\mathrm{kr}_{\mathrm{b} 1}$, reddish-brown - $\mathrm{kr}_{\mathrm{b} 2}$ ), Shyrokyno (cinnamonishbrown $-\mathrm{sh}_{\mathrm{b} 1}$, reddish cinnamon $-\mathrm{sh}_{\mathrm{b} 2}$ ) and Martonosha (dark-colored (meadow-reddish-brown) merged $\mathrm{mr}_{\mathrm{b} 2}+\mathrm{mr}_{\mathrm{b} 1}$, reddish-cinnamon brownish fused saline

Table 1. Paleogeographic conditions of the Pleistocene in the Azov lowland (Veklych, 1982, 1987; Krokhmal, Rekovets 2010; Sirenko, Turlo 1986.)

\begin{tabular}{|c|c|c|c|c|}
\hline Stage & $\begin{array}{c}\text { The type of soils which studied } \\
\text { palaeopedologically by the } \\
\text { author sites (vil. of Bezimenne, } \\
\text { Melekine) }\end{array}$ & $\begin{array}{c}\text { The general types of } \\
\text { vegetation (Sirenko, Turlo } \\
\text { 1986) }\end{array}$ & $\begin{array}{l}\text { Faunistic complexes } \\
\text { for large mammals } \\
\text { (Krokhmal, Rekovets } \\
\text { 2010) }\end{array}$ & $\begin{array}{l}\text { Climate (average annual } \\
\text { temperature, }{ }^{\circ} \text { C: January/ } \\
\text { July; annual rainfall, mm } \\
\text { (Veklych, 1982, 1987; } \\
\text { Sirenko, Turlo 1986) }\end{array}$ \\
\hline df & $\begin{array}{l}\text { chernozem saline }\left(\mathrm{df}_{\mathrm{b} 2}\right) \text {, brown } \\
\text { saline }\left(\mathrm{df}_{\mathrm{c}}\right) \text {, brown desert-steppe } \\
(\mathrm{df})\end{array}$ & $\begin{array}{l}\text { grass-graze-polynomial- } \\
\text { loboda steppes }\end{array}$ & \multirow{3}{*}{$\begin{array}{l}\text { Upper paleolithic } \\
\text { (Mammuthus } \\
\text { primigenius) }\end{array}$} & $\begin{array}{l}\text { moderate dry }(-6--9 /+17- \\
+18 ; 300-400)\end{array}$ \\
\hline vt & cinnamonish-brown $\left(\mathrm{vt}_{\mathrm{b} 2}\right)$ & $\begin{array}{l}\text { grass-gravel steppes and } \\
\text { ravine forests }\end{array}$ & & $\begin{array}{l}\text { moderately warm subarids }(-3- \\
-5 /+18-+20 ; 350-450)\end{array}$ \\
\hline pl & $\begin{array}{l}\text { cinnamonish -gray saline }\left(\mathrm{pl}_{\mathrm{b} 1}\right) \text {, } \\
\text { chernozem saline }\left(\mathrm{pl}_{\mathrm{b} 2}\right), \text { brown } \\
\text { steppe }\left(\mathrm{pl}_{1}\right)\end{array}$ & grass-gravel steppes & & $\begin{array}{l}\text { moderately warm }(0-+1 /+21- \\
+22 ; 450-700)\end{array}$ \\
\hline kd & $\begin{array}{l}\text { cinnamonish-brown }\left(\mathrm{kd}_{\mathrm{b} 1}\right) \\
\text { chernozems ordinary }\left(\mathrm{kd}_{\mathrm{b} 2}\right)\end{array}$ & $\begin{array}{l}\text { grass-gravel steppes and } \\
\text { ravine forests }\end{array}$ & $\begin{array}{l}\text { Khazar } \\
\text { (Mammuthus } \\
\text { chosaricus) }\end{array}$ & $\begin{array}{l}\text { moderately warm }(-2--3 / \\
+20-+21 ; 550-700)\end{array}$ \\
\hline $\mathbf{z V}$ & $\begin{array}{l}\text { cinnamon }\left(\mathrm{zv}_{\mathrm{b} 1}\right), \text { reddish- } \\
\text { cinnamon saline }\left(\mathrm{zv}_{\mathrm{b} 2}\right)\end{array}$ & $\begin{array}{l}\text { forest-steppe with broadleaf } \\
\text { pine forests with elements } \\
\text { of Pliocene flora with grass- } \\
\text { mixed grass steppes }\end{array}$ & $\begin{array}{l}\text { Singh } \\
\text { (Palaeoloxodon } \\
\text { antiquus) }\end{array}$ & $\begin{array}{l}\text { moderately variable and } \\
\text { humid close to subtropical (0- } \\
+2 /+22-+23 ; 400-600)\end{array}$ \\
\hline lb & $\begin{array}{l}\text { reddish-brown saline }\left(\mathrm{lb}_{\mathrm{b} 2}\right) \text {, dark- } \\
\text { colored fused }\left(\mathrm{lb}_{\mathrm{b} 2}+\mathrm{lb}_{\mathrm{b} 1}\right)\end{array}$ & $\begin{array}{l}\text { forest-steppe with broadleaf- } \\
\text { pine forests with elements of } \\
\text { Pliocene flora and meadow } \\
\text { steppes }\end{array}$ & \multirow{2}{*}{$\begin{array}{l}\text { Tiraspol } \\
\text { (Archidiskodon } \\
\text { trogontherii) }\end{array}$} & $\begin{array}{l}\text { moderately warm transition to } \\
\text { subtropical }(-1-+1 /+21-+22 \\
550-900)\end{array}$ \\
\hline $\mathbf{m r}$ & $\begin{array}{l}\text { dark-colored merged }\left(\mathrm{mr}_{3}+\mathrm{mr}_{2}\right. \\
\left.+\mathrm{mr}_{1}\right) \text {, reddish-cinnamon fused } \\
\text { saline }\left(\mathrm{mr}_{3}\right)\end{array}$ & $\begin{array}{l}\text { forest-steppe with broadleaf- } \\
\text { coniferous forests with } \\
\text { elements of the Pliocene flora } \\
\text { and mesotic steppes }\end{array}$ & & $\begin{array}{l}\text { warm-moderately close to } \\
\text { subtropical }(+1-+2 /+22-+23 \\
650-750)\end{array}$ \\
\hline sh & $\begin{array}{l}\text { cinnamon }\left(\mathrm{sh}_{\mathrm{b} 1}\right) \text {, reddish- } \\
\text { cinnamon }\left(\mathrm{sh}_{\mathrm{b} 2}\right)\end{array}$ & $\begin{array}{l}\text { forest-steppe with broadleaf- } \\
\text { coniferous forests with } \\
\text { elements of heat-loving } \\
\text { flora and meadow-steppe } \\
\text { herbaceous vegetation }\end{array}$ & $\begin{array}{l}\text { Taman } \\
\text { (Archidiskodon } \\
\text { meridionalis } \\
\text { tamanensis) }\end{array}$ & $\begin{array}{l}\text { warm-moderate close to } \\
\text { subtropical arid }(+1-+3 /+22- \\
+24 ; 550-650)\end{array}$ \\
\hline kr & $\begin{array}{l}\text { reddish-cinnamon }\left(\mathrm{kr}_{\mathrm{b} 1}\right) \text {, reddish- } \\
\text { brown }\left(\mathrm{kr}_{\mathrm{b} 2}\right)\end{array}$ & $\begin{array}{l}\text { forest-steppe with broadleaf } \\
\text { coniferous forests including } \\
\text { elements of heat-loving flora } \\
\text { and grassy steppes }\end{array}$ & $\begin{array}{l}\text { Pseudo } \\
\text { (Archidiskodon } \\
\text { meridionalis } \\
\text { meridionalis) }\end{array}$ & $\begin{array}{l}\text { warm-tempered with signs of } \\
\text { subtropical }(+2-+4 /+22-+23 \text {; } \\
500-600)\end{array}$ \\
\hline
\end{tabular}


- $\mathrm{mr}_{3}$ ) soils, which are distinguished by reddish shades of color, are the most clayed, ferruginous with a large number of nodules which concentration organ-iron-clay material; the bixed morpho- and micromorphological features indicate that such types of soils could only be formed in the heat-temperate with signs of subtropical or climatic conditions close to them;

- Lubny (red-brown saline - $\mathrm{lb}_{\mathrm{b} 2}$, dark-colored (brownish-cinnamon) fused $-\mathrm{lb}_{\mathrm{b} 2}+\mathrm{lb}_{\mathrm{b} 1}$ ), heavy loam soils, are less clayed, ferruginous, different by browngray a brownish tinge with the color of their profiles, the presence of moleholes, complex microagregation; such features of the morpho- and microstructure of these soils are evidence of their formation in the meadow-steppe and steppe conditions of a moderately warm transition to a subtropical climate;

- Zavadivka (cinnamon and cinnamon saline $\mathrm{zv}_{\mathrm{b} 1}$, reddish-brown saline $-\mathrm{zv}_{\mathrm{b} 2}$ ), heavy loam soils, which are a transitional variant to the temperate climate, although some features of the lower Pleistocene soil formation remain (ferrugination, presence of segregation clusters of organo-clay and clay materials, microortshteins) and probably formed in moderate variably-wet close to subtropical climatic conditions;

- Kaydaky (cinnamonish-brown $-\mathrm{kd}_{\mathrm{b} 1}$, chernozems ordinary $-\mathrm{kd}_{\mathrm{b} 2}$ ) and Pryluky (cinnamonish-gray saline $-\mathrm{pl}_{\mathrm{b} 1}$, chernozems saline $\mathrm{pl}_{\mathrm{b} 2}$ ), brown steppe $-\mathrm{pl}_{\mathrm{c}}$ ), heavy and medium loam soils are characterized by grayish shades of their profiles coloring, presence moleholes, carbonates, complex microaggregates, pores; the listed signs indicate that these soils were formed in moderately warm, uniformly humid climatic conditions; they are the closest to the modern soils that are currently distributed in the territory of Ukraine;

- Vytachiv (cinnamonish-brown - $\mathrm{vt}_{\mathrm{b} 2}$ ) heavy loam soils formed under the influence of turf (the presence of moleholes, carbonate, complex microaggregates) and brownzem-liked (cinnamonishbrown coloration of the profile, spatial structure of clays) of the soil forming processes of a moderately warm subarid climate and have no analogues in the modern soil cover of our country;

- Dofinivka (chernozem saline - $\mathrm{df}_{\mathrm{b} 2}$, brown saline and brown desert-steppe $-\mathrm{df}$ ), medium loam soils, with clear features of xeromorphism (low profile power, its carbonaceous nature, absence of signs of organo-mineral material redistribution), formed in moderately continental and more arid (dry) climatic conditions compared with modern ones.

The established types of Pleistocene soils, their morphological and micromorphological features reflect changes in paleogeographic conditions from Kryzhanivka, Shyrokyno, Martonosha, Lubny and Zavadivka paleogeographical stages, soils formed in warm-temperate climatic conditions with signs of subtropical or close to them. The established types of soils of the Kaydaky, Pryluky, Vytachiv and Dofinivka stages are evidence of their formation in temperate climates.

\section{References}

Veklych, M.F. 1968. Stratigrafiya lessovoy formatsii Ukrainyi i sosednih stran [Stratigraphy of the loess formation of Ukraine and neighboring countries]. Naukova Dumka, Kyiv (in Russian).

Veklych M.F., Sirenko N.A. 1972. Opornyie geologicheskie razrezyi antropogena Ukrainyi. Ch.III. [Reference geological sections of anthropogene of Ukraine. Part III.]. Naukova Dumka, Kyiv (in Russian).

Veklych M.F., Sirenko N.O., Dubnyak V.O. Maiska Zh.M., Melnychuk I.V., Paryshkura S.I. 1973. Rozvytok gruntiv Ukrainy v piznomu kainozoi [Development of Ukraine's soils in the Late Cenozoic]. Naukova Dumka, Kyiv (in Ukrainian).

Veklych M.F., Matviishyna Zh.N., Medvedev V.V., Sirenko N.A., Fedorov K.N. 1979. Metodika paleopedologicheskih issledovaniy [Method of palaeopedological research]. Naukova Dumka, Kyiv (in Russian).

Veklych M.F. 1982. Paleoetapnost i stratotipyi pochvennyih formatsiy verhnego kaynozoya Ukrainyi [Paleostepping and stratotypes of soil formations of the Upper Cenozoic of Ukraine]. Naukova Dumka, Kyiv (in Russian).

Veklych M.F. 1987. Problemyi paleoklimatologii [Problems of paleoclimalology]. Naukova Dumka, Kyiv (in Russian).

Veklych M.F., Sirenko N.A., Turlo S.I., Matviishina Zh.N. 1993. Stratigraficheskaya shema chetvertichnyih otlozheniy Ukrainyi [Stratigraphic scheme of the Pleistocene deposits of Ukraine]. State Committee of Geology of Ukraine, Kyiv (in Russian).

Gozhik P.F., Cemenenko V.M., Poletaev V.I., Ivanik M.M., Velikanov V.Ya. Maslu, N.V., Konstantinenko L.I., Andreeva-Grigorovich A.S., Zosimovich V.Yu., Shovkoplyas V.M. 2012. StratigrafIchniy kodeks Ukrayini [Stratigraphic Code of Ukraine]. Logos, Kyiv (in Ukrainian).

Karmazinenko S.P. 2010. Mikromorfologichni doslidzhennya vikopnih i suchasnih Gruntiv Ukrayini [Micromorphological studies of fossil and modern soils of Ukraine]. Naukova Dumka, Kyiv (in Ukrainian).

Karmazinenko S.P. 2013. Paleopedolohichna kharakterystyka chetvdertynnykh vidkladiv bilia s.Bezimenne Donetskoi oblasti [Paleopedological 
characterization of Quaternary sediments near the village Bezimenne of Donetsk region]. The collection of scientific works «Modern problems of geological sciences», Kyiv, 144-153 (in Ukrainian).

Karmazinenko S.P. 2014. Pleistotsenovi grunty Pryazovskoi nyzovyny [Pleistocene soils of Azov Lowland]. Geopolitics and eco-geodynamics of the regions. Vol. 10, Vip.1. Simferopol, 585-593 (in Ukrainian).

Karmazinenko S.P. 2017. Paleopedolohichni doslidzhennia pleistotsenovykh gruntiv na terytorii Pryazovskoi nyzovyny [Paleopedological studies of Pleistocene soils in the Azov Lowland]. UkrDGRI, Kyiv, 163167 (in Ukrainian).
Krokhmal A.I., Rekovets L.I. 2010. Mestonahozhdeniya melkih mlekopitayuschih pleystotsena Ukrainyi I sopredelnyih territoriy [The locations of small mammals of the Pleistocene of Ukraine and adjacent territories]. LAT $£$ K, Kyiv (in Russian).

Matviishyna Zh.N. 1982. Mikromorfologiya pleystotsenovyihpochvUkrainyi[Micromorphology of the Pleistocene soils of Ukraine]. Naukova Dumka, Kyiv (in Russian).

Sirenko N.A. Turlo S.I. 1986. Razvitie pochv i rastitelnosti Ukrainyi v pliotsene i pleystotsene [The development of soils and vegetation of Ukraine in the Pliocene and Pleistocene]. Naukova Dumka, Kyiv (in Russian). 